\title{
Respiratory Energy Losses in Podophrya fixa Müller in Relation to Temperature and Nutritional Status
}

\author{
By JOHANNA LAYBOURN \\ Department of Biology, University of Stirling, Stirling $F K 9{ }_{4} L A$
}

(Received 26 March 1976 )

SUMMAR Y

Respiration in well-fed and starved Podophrya fixa was measured by means of Cartesian diver microrespirometry at $5{ }^{\circ} \mathrm{C}$ intervals between $10{ }^{\circ} \mathrm{C}$ and $30^{\circ} \mathrm{C}$. At $10{ }^{\circ} \mathrm{C}$ encystment occurred. The optimum temperature for respiration was $25^{\circ} \mathrm{C}$ where a rate of $4 \mathrm{I} \cdot 3 \times \mathrm{IO}^{-6} \mu \mathrm{l} \mathrm{h}^{-1}$ per individual was recorded in well-fed animals. Mean cell size also reached a maximum at $25^{\circ} \mathrm{C}$ in well-fed individuals. Both respiration rate and mean cell size decreased with starvation, as did the rate of metabolism. A table of daily respiratory energy losses in well-fed and starved Podophrya is presented. The results and their implications are discussed in relation to other protozoa.

\section{INTRODUCTION}

In recent years, interest in the energetics of protozoan species has grown, largely because so little is known of the role and energy relationships of small invertebrates such as protozoa, nematodes and rotifers, in the natural environment. Few complete energy budgets exist for protozoans, except for Acanthamoeba spp. (Heal, 1967) and Stentor coeruleus (Laybourn, 1976); but there have been many detailed investigations into what may be described as the feeding and growth energetics of protozoans, for example in Tetrahymena pyriformis (Curds \& Cockburn, 1968, 1971), in Entodinium caudatum (Coleman, 1964) and Colpidium campylum (Laybourn \& Stewart, 1975).

Very little data has been published on respiratory energy losses in protozoan species at normal environmental temperatures. The present investigation into respiratory energy losses in Podophrya fixa was undertaken to elucidate the temperature range of the species and to determine the effect of nutritional status on the rate of metabolism. Podophrya is a sedentary carnivorous suctorian species which produces motile ciliated 'larvae' by endogenous budding. When starved, reproduction ceases; but Podophrya can survive for many days without food and resume normal feeding and reproduction when the food supply is restored.

\section{METHODS}

Oxygen consumption. Oxygen consumption was determined in small stoppered Cartesian divers (Linderstrøm-Lang, I943; Klekowski, I97I) of between 0.60 and I $00 \mu \mathrm{l}$ gas phase. The number of suctorians per diver was between 20 and 40 , depending on the experimental temperature and nutritional state of the animals. The organisms were washed through five changes of sterile soil extract medium (Vickerman \& Cox, 1967) to remove adhering bacteria. They were then drawn into a calibrated breaking pipette into which the length of air which constituted the gas phase of the diver had already been inserted. In this way both the organisms and the gas phase were introduced into the diver in one manipulation. Controls 
were run on the final washing medium used in preparing the organisms in order to determine if any bacterial respiration was present.

Experiments were carried out at 10, 15, 20, 25 and $30^{\circ} \mathrm{C}$. At each temperature, oxygen consumption was determined in well-fed animals and animals starved for $48 \mathrm{~h}$ and $96 \mathrm{~h}$. Five replicate experiments were conducted in each case.

An oxycaloric coefficient of $4.825 \mathrm{cal} / \mathrm{ml}$ oxygen (Phillipson, 1970) was used to convert values of oxygen consumed into units of energy. The SI unit of energy, the joule, is used in the present study ( $\mathrm{I}$ cal $=4 \cdot \mathrm{I} 84 \mathrm{~J})$.

Organism. Podophrya fixa, fed on Colpidium, was maintained in heavy watch-glasses filled with soil extract medium at the appropriate experimental temperature, so that the animals should be fully acclimatized. Animals which were to be starved were moved from the culture dishes to other dishes without food and incubated at the intended experimental temperature for either 48 or $96 \mathrm{~h}$.

Determination of mean cell volume. Podophrya fixa is spherical and so cell volume may be calculated by employing the formula $\frac{4}{3} \pi r^{3}$. For each set of five replicate experiments, 50 animals from the same culture were measured using a high-power microscope with a calibrated graticule in the eyepiece. Cell weights were obtained by using a conversion factor for protozoan protoplasm derived from calorimetry studies (Laybourn, 1973).

\section{RESULTS}

The oxygen consumption per individual Podophrya in relation to temperature is shown in Fig. I. At $10{ }^{\circ} \mathrm{C}$ they underwent encystment despite the presence of abundant food organisms. Attempts to measure respiration in the cysts proved unsuccessful; even when 60 cysts were contained in one diver, the changes in pressure recorded on the respirometer manometer were so small that no reliable result was obtained. Between $15{ }^{\circ} \mathrm{C}$ and $25^{\circ} \mathrm{C}$, oxygen consumption by well-fed animals rose to a maximum rate of $4 \mathrm{I} \cdot 3 \times 10^{-6} \mu 1 \mathrm{~h}^{-1}$ per individual. Above $25^{\circ} \mathrm{C}$, oxygen consumption decreased sharply to a mean rate of $12 \cdot 15 \times$ $\mathrm{IO}^{-6} \mu \mathrm{l} \mathrm{h}-1$ per individual at $30^{\circ} \mathrm{C}$. Starved animals exhibited much lower respiration rates; when starved for 48 or $96 \mathrm{~h}$, the peak rate of oxygen consumption occurred between $20^{\circ} \mathrm{C}$ and $25{ }^{\circ} \mathrm{C}$, thereafter declining gradually (Fig. I). The magnitude of the acceleration of the respiratory process up to the optimum rate, expressed as $Q_{10}$, was 5.789 between $15{ }^{\circ} \mathrm{C}$ and $20^{\circ} \mathrm{C}$, and 3.754 between $20^{\circ} \mathrm{C}$ and $25^{\circ} \mathrm{C}$ in well-fed animals. In starved individuals $Q_{10}$ between $15{ }^{\circ} \mathrm{C}$ and $20{ }^{\circ} \mathrm{C}$ was 2.567 after $48 \mathrm{~h}$ starvation and 2.888 after $96 \mathrm{~h}$ starvation.

The mean cell volume of Podophrya was also a function of temperature and nutritional state (Fig. 2). In well-fed individuals, the mean cell size was similar between $15{ }^{\circ} \mathrm{C}$ and $20^{\circ} \mathrm{C}$, and was between a mean of $47902 \mu \mathrm{m}^{3}$ at $15^{\circ} \mathrm{C}$ and $49512 \mu \mathrm{m}^{3}$ at $20{ }^{\circ} \mathrm{C}$. At $25^{\circ} \mathrm{C}$ the mean cell volume showed a sharp increase to $6 \mathrm{I} \mathrm{I} 23 \mu \mathrm{m}^{3}$, but above $25^{\circ} \mathrm{C}$ it decreased. Cell size in starved animals progressively decreased between $15^{\circ} \mathrm{C}$ and $30^{\circ} \mathrm{C}$, and their volumes were very much smaller with a maximum mean cell volume at $15{ }^{\circ} \mathrm{C}$ of $20893 \mu \mathrm{m}^{3}$ after $48 \mathrm{~h}$ starvation and $16892 \mu \mathrm{m}^{3}$ after $96 \mathrm{~h}$ starvation.

Podophrya depresses its metabolism during starvation, and the extent to which this occurred becomes clearer if oxygen uptake is expressed in terms of respiration rate per unit body or cell weight (Fig. 3). Only at $15{ }^{\circ} \mathrm{C}$ do starved, and consequently small, Podophrya have a higher rate of oxygen uptake per unit body weight than large well-fed individuals. At all other temperatures examined, the rate is similar or lower in small animals.

Daily respiratory energy losses in Podophrya are given in Table I. 


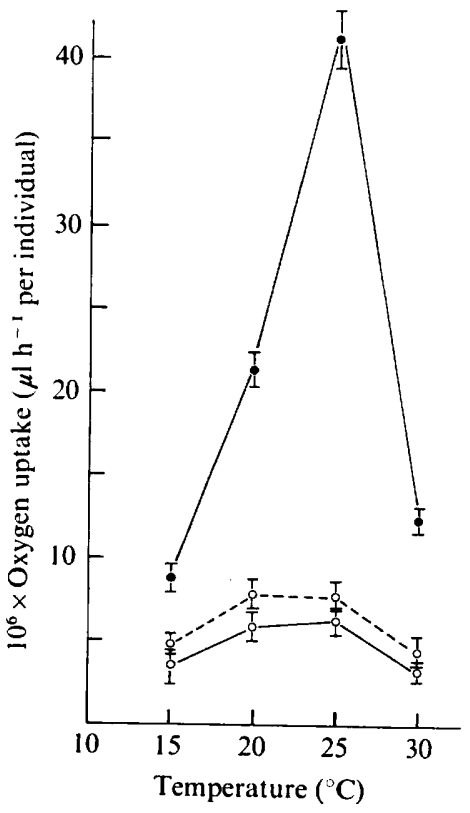

Fig. I

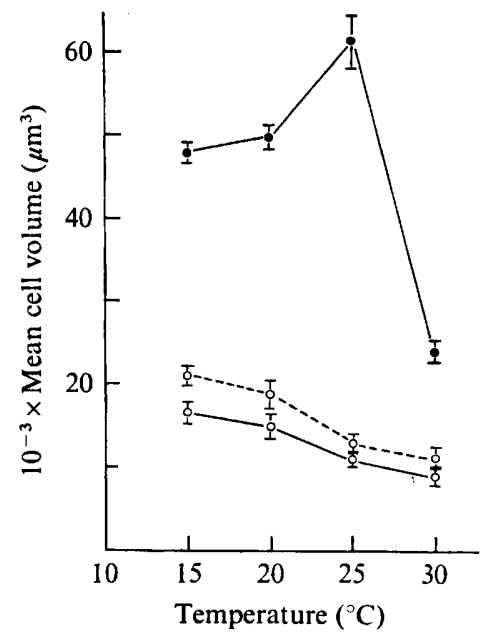

Fig. 2

Fig. I. Oxygen consumption in individual Podophrya fixa. Vertical lines indicate standard errors. -, Well-fed animals; $\bigcirc---\bigcirc$, animals starved for $48 \mathrm{~h} ; \bigcirc-\bigcirc$, animals starved for $96 \mathrm{~h}$. Fig. 2. Mean cell volumes of Podophrya fixa. Vertical lines indicate standard errors. $\mathbf{0}$, Wellfed animals; $\bigcirc---O$, animals starved for $48 \mathrm{~h} ; \mathrm{O}-\mathrm{O}$, animals starved for $96 \mathrm{~h}$.

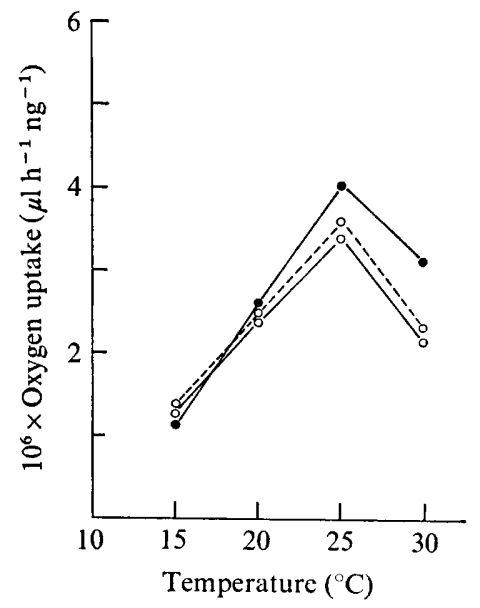

Fig. 3. Oxygen consumption of Podophrya fixa per unit body weight. '- Well-fed animals; $\bigcirc---\bigcirc$, animals starved for $48 \mathrm{~h}$; $\bigcirc-\bigcirc$, animals starved for $96 \mathrm{~h}$. 
Table I. Daily respiratory energy losses $(R)$ in Podophrya fixa

\begin{tabular}{|c|c|c|c|c|c|c|c|c|c|}
\hline \multirow[b]{2}{*}{$\begin{array}{l}\text { Temp. } \\
\left({ }^{\circ} \mathrm{C}\right)\end{array}$} & \multicolumn{3}{|c|}{ Well-fed } & \multicolumn{3}{|c|}{ Starved for $48 \mathrm{~h}$} & \multicolumn{3}{|c|}{ Starved for $96 \mathrm{~h}$} \\
\hline & $\begin{array}{c}\text { Dry wt } \\
\text { (ng) }\end{array}$ & $\begin{array}{c}R \\
\text { (nJ } / 24 \mathrm{~h})\end{array}$ & S.E.M. & $\begin{array}{c}\text { Dry wt } \\
\text { (ng) }\end{array}$ & $\begin{array}{c}R \\
\text { (nJ } / 24 \mathrm{~h} \text { ) }\end{array}$ & S.E.M. & $\begin{array}{l}\text { Dry wt } \\
\text { (ng) }\end{array}$ & $\begin{array}{c}R \\
\text { (nJ/24 h) }\end{array}$ & S.E.M. \\
\hline 15 & $8 \cdot 14$ & 4278 & 367 & 3.65 & 2387 & 308 & $2 \cdot 87$ & 1684 & 482 \\
\hline 20 & 8.42 & 10308 & 757 & $3 \cdot 19$ & 3825 & 680 & $2 \cdot 53$ & 3709 & 842 \\
\hline 25 & $10 \cdot 39$ & 19942 & 1669 & $2 \cdot 16$ & 2860 & 308 & 1.85 & 2995 & 308 \\
\hline 30 & 3.96 & $586 \mathrm{I}$ & 308 & $1 \cdot 85$ & 2030 & 482 & $1 \cdot 43$ & I 447 & 390 \\
\hline
\end{tabular}

\section{DISCUSSION}

The only other known investigation of respiration in Podophrya was that undertaken by Hull (196I). He used Cartesian diver microrespirometry, and quotes oxygen consumption rates of $320 \mu \mathrm{l} / \mathrm{IO} \mathrm{min}$ per individual at $28 \cdot 5{ }^{\circ} \mathrm{C}$ (i.e. $1920 \mu 1 \mathrm{~h}^{-1}$ ). Hull also measured the respiration rate of Paramecium, a prey organism in his study, and found rates of $800 \mu \mathrm{l} /$ Io min per individual (i.e. $4800 \mu \mathrm{l} \mathrm{h}^{-1}$ ). Such respiration rates are extremely high for protozoans. Paramecium has been widely studied and rates between $\mathrm{I} \cdot 22 \times 10^{-4}$ and $5.5 \mathrm{I} \times$ $\mathrm{I}^{-4} \mu 1 \mathrm{~h}^{-1}$ per individual at temperatures ranging between $20^{\circ} \mathrm{C}$ and $26^{\circ} \mathrm{C}$ have been reported (Kalmus, I928; Howland \& Bernstein, 193I; Stewart \& Pringle, I96I).

Compared with other small active protozoa, the Podophrya in the present study have a low rate of respiration. Tetrahymena, for example, which is similar in size to Podophrya, has a respiration rate of $\mathrm{I} \cdot 5 \times 10^{-4}$ to $7 \cdot 8 \times 10^{-4} \mu \mathrm{l} \mathrm{h}-1$ per individual at $26^{\circ} \mathrm{C}$ (Løvlie, I963). However, sedentary protozoa tend to have lower rates of respiration than more active protozoan species. Stentor coeruleus, a large sedentary species, has an hourly respiration rate of $\mathrm{I} \cdot 5 \times 10^{-4}$ to $3.0 \times 10^{-4} \mu 1$ per individual at $20^{\circ} \mathrm{C}$ and $\mathrm{I} \cdot 5 \times \mathrm{IO}^{-4}$ to $\mathrm{I} \cdot 8 \times 10^{-4} \mu 1$ per individual at $15{ }^{\circ} \mathrm{C}$ in animals weighing $860 \mathrm{ng}$ (Laybourn, 1975), while at 24 to $25^{\circ} \mathrm{C}$ a rate of $0.43 \times 10^{-4} \mu \mathrm{l}$ per individual has been reported (Sarojini \& Nagabhushanam, 1967).

Vorticella sp. has a respiration rate of $0.166 \times 10^{-4} \mu \mathrm{lh}^{-1}$ per individual at $15{ }^{\circ} \mathrm{C}$ for animals weighing $5 . \mathrm{I} \mathrm{ng}$ and $0.098 \times 10^{-4} \mu \mathrm{l} \mathrm{h}-1$ per individual at $20^{\circ} \mathrm{C}$ for animals weighing $4.42 \mathrm{ng}$ (Laybourn \& Finlay, 1976). Thus the respiration rates obtained here compare closely with those reported for other sedentary protozoa, allowing for weight and optimum temperature differences.

The effect of temperature on the rate of oxygen uptake in protozoans has formed the basis of several studies. An optimum temperature for respiration of $25^{\circ} \mathrm{C}$ has been found in Spirostomum ambiguum (Sarojini \& Nagabhushanam, 1966) and in Tetrahymena gelii (Pace \& Lyman, 1947). The optimum temperature for normal well-fed Podophrya fixa was also $25^{\circ} \mathrm{C}$. Other species, such as Paramecium aurelia and Paramecium caudatum, show a progressive rise in respiration rate between $15{ }^{\circ} \mathrm{C}$ and $35^{\circ} \mathrm{C}$ (Pace \& Kimura, 1944), so in these species the optimum temperature must be very much higher than in Podophrya, Tetrahymena and Spirostomum. The optimum temperature for respiration has ecological significance, since it must be one of the determining factors in the seasonal distribution and abundance of ciliate species.

Within a given species, smaller animals have higher respiration rates per unit body weight than larger individuals. Data available for the ciliate Stentor coeruleus (Laybourn, 1975), for example, show that individuals of $200 \mathrm{ng}$ dry wt have an hourly respiration rate per $\mathrm{ng}$ that is $27 \%$ higher than that of animals weighing $1000 \mathrm{ng}$. In starved Podophrya, the rate of oxygen uptake per unit weight was lower than in the larger well-fed individuals, which suggests that the rate of metabolism was greatly reduced during starvation. The changes in 
metabolism and cell size induced by starvation have been considered in other protozoan species. Paramecium caudatum decreases its rate of oxygen uptake by $29 \%$ after $12 \mathrm{~h}$ without food at $20{ }^{\circ} \mathrm{C}$, and the reduced rate of respiration is accompanied by a progressive decrease in cell size (Leichsenring, 1925). In Podophrya, the greatest percentage decrease in respiration occurred at $25^{\circ} \mathrm{C}$. At this temperature the rate decreased by $84.9 \%$ after $96 \mathrm{~h}$ without food, but the basic pattern manifested by starvation was similar to that in $P$. caudatum, with decreased respiration and reduced cell volume. Chaos chaos, a large species of carnivorous amoeba which usually dies about a month after the initiation of starvation, decreases its cell volume to about a quarter by the time death occurs (Holter \& Zeuthen, 1947). Holter \& Zeuthen also found that in Chaos the ratio between respiratory rate and reduced weight was constant and independent of the shrinkage of the amoebae. This suggests that in Chaos the rate of respiration per unit weight was constant throughout starvation, whereas in Podophrya the rate of metabolism per unit weight decreased as starvation progressed. Moreover, the reduction in the rate of metabolism was more pronounced at higher temperatures. The ability to reduce substantially its rate of metabolism, so as to conserve energy during periods of starvation, is advantageous to a sedentary organism such as Podophrya which is unable to swim and search for food.

This work was financed by a Natural Environmental Research Council Postdoctoral Research Fellowship.

\section{REFERENCES}

Coleman, G. S. (1964). The metabolism of Escherichia coli and other bacteria by Entodinium caudatum. Journal of General Microbiology 37, 209-223.

Curds, C. R. \& Cockburn, A. (1968). Studies on the growth and feeding of Tetrahymena pyriformis in axenic and monoxenic culture. Journal of General Microbiology 54, 343-358.

Curds, C. R. \& Cockburn, A. (I97I). Continuous monoxenic culture of Tetrahymena pyriformis. Journal of General Microbiology 66, 95-108.

Heal, O. W. (1967). Quantitative studies on soil amoebae. In Progress in Soil Biology, pp. I20-126. Edited by O. Graff and J. E. Satchell. Amsterdam: North Holland Publishing Co.

Holter, H. \& Zeuthen, E. (1947). Metabolism and reduced weight in starving Chaos chaos. Comptes rendus des travaux du Laboratoire Carlsberg 26, 277-296.

Howland, R. B. \& Bernstein, A. (193I). A method of determining the oxygen consumption of a single cell. Journal of General Physiology 14, 339-348.

Hull, R. W. (I96I). Studies on suctorian protozoa: the mechanism of ingestion of prey cytoplasm. Journal of Protozoology 8, 35I-359.

Kalmus, H. (1928). Untersuchungen über die Atmung von Paramecium caudatum. Zeitschrift für vergleichende Physiologie 7, 304-310.

KLEKowsKi, R. Z. (I97I). Cartesian diver microrespirometry for aquatic animals. Polskie archiwum hydrobiologii $18,93-114$.

LAYBOURN, J. E. M. (1973). The energetics of Colpidium campylum Stokes with a note on the vertical distribution of Ciliophora in the mud of Loch Leven, Kinross. Ph.D. thesis, University of Stirling.

Laybourn, J. (1975). Respiratory energy losses in Stentor coeruleus Ehrenberg (Ciliophora). Oecologia (Berlin) 2r, 273-278.

Laybourn, J. (I976). Energy budgets for Stentor coeruleus (Ciliophora). Oecologia (Berlin) 22, 43I-437.

Laybourn, J. \& Finlay, B. J. (I976). Respiration in ciliated protozoa in relation to cell size and temperature. Oecologia (Berlin) (in the Press).

Laybourn, J. E. M. \& Stewart, J. M. (1975). Studies on consumption and growth in the ciliate Colpidium campylum Stokes. Journal of Animal Ecology 44, I65-1 74.

LEICHSENRING, J. M. (I925). Factors influencing the rate of oxygen uptake in single cells. American Journal of Physiology 75, 84-92.

LinderstrøM-LANG, K. (1943). On the theory of the cartesian diver microrespirometer. Comptes rendus des travaux du Laboratoire Carlsberg 24, 333-398.

Løvle, A. (1963). Growth in mass and respiration rate during the cell cycle of Tetrahymena pyriformis. Comptes rendus des travaux du Laboratoire Carlsberg 33, 377-413.

PaCe, D. M. \& Kimura, K. K. (I944). The effect of temperature on the respiration of $P$. caudatum and P. aurelia. Journal of Cellular and Comparative Physiology 24(3), I73-I83. 
PACE, D. M. \& Lyman, E. D. (1947). Oxygen consumption and carbon dioxide elimination in Tetrahymena gelii. Biological Bulletin, Marine Biological Laboratory, Woods Hole, Mass. 92, 210-2 16.

Phillipson, J. (1970). The 'best estimate' of respiratory metabolism: its applicability to field situations. Polskie archiwum hydrobiologii 17, 3I-4I.

Sarojini, R. \& Nagabhushanam, R. (I966). Exogenous factcrs affecting respiration in the ciliate Spirostomum ambiguum. Journal of Animal Morphology and Physiology 13, 95-102.

SARojini, R. \& NAGABhushanam, R. (1967). A comparative study of the respiration of some free-living ciliated protozoa. Journal of Animal Morphology and Physiology 14, I 58-167.

Stewart, J. M. \& Pringle, C. R. (I96I). Rate of respiration in relation to autogamy in Paramecium aurelia. Experientia 17, 73-74.

Vickerman, K. \& Cox, F. G. (1967). Introductory Series in Biology: The Protozoa, p. 52. London: John Murray. 